\title{
Organization and Assessment of Efficiency of Intra Corporate Control in the Large Coal Mining Company
}

\author{
Kucherova Elena V. a, Tyuleneva Tatyana A. , \\ T. F. Gorbachev Kuzbass State Technical University \\ Kemerovo, Russian Federation \\ abuia@yandex.ru, ${ }^{b}$ krukta@mail.ru
}

\author{
Cherepanova Natalya A. \\ SUEK Kuzbass open joint stock company, \\ Leninsk-Kuznetsk Kemerovo region Russian Federation \\ cherepanovana@suek.ru
}

\begin{abstract}
The paper describes the need of improvement of intra corporate control of the enterprise of the coal-mining industry. The description of the principles of creation, model of realization of intra corporate control as sets of mechanisms of its organization and an assessment, and also stages of their application are given. It also describes the analysis of the financial indicators of efficiency of activity of the coal-mining industry enterprise, for an assessment of productivity of the system of intra corporate control. The main result of research is the new method of solution of the problem of creation of intra corporate control system using a matrix of control procedures for the assessment of risks for business processes taking into account the branch specifics. This method will increase efficiency of management decision-making on productivity of business processes
\end{abstract}

Keywords - Intra corporate control; system of intra corporate control; assessment mechanism; matrix of risks and business processes; instruments of control

\section{INTRODUCTION}

The adverse economic situation in the conditions of the resource oriented economy (the oil and gas income makes nearly a half of revenues of the budget, and minerals account for about $2 / 3$ of the Russian exports) is the strongest motivation for economic entities to search the reserves, ways of costs optimization and new opportunities for increase of efficiency of business [1, 2, 3]. Considering the need for the coal-mining enterprises to keep positions in the market at the existing tendencies of the industry development, in the management activity it is very important to find solutions to the problems of costs reduction and maximizing of revenue. Therefore, in the conditions of coal prices decrease enterprises make considerable efforts on ensuring increase in production. Due to the fact that the production of coal production is largely capital intensive and based on the size of the coal enterprises, even small in relation to the specific cost reduction or increase in production volumes gives a significant effect much greater than the costs. The relevance of the research topic is determined by the need to improve the efficiency of the company through the development and use of models and algorithms for the organization and evaluation of the effectiveness of internal corporate controls, due to its special role in the corporation The analysis of works by Russian and foreign authors on this problem allowed us to summarize the existing experience in organization of monitoring, identify the problems and the lack of study of these issues. Views on the organization of internal control are based on various methodological approaches which are insufficiently theoretically proved. All these problems allow to draw a conclusion on need of improvement of system of the organization of intra corporate control and an assessment of its efficiency.

\section{OBJECT OF RESEARCH}

The object of research in this paper is JSC SUEK-Kuzbass. It is one of the largest coal-mining companies of holding type in Kuzbass. This enterprise is taken as an example for description of the principles of the organization of intra corporate control.

The plans of JSC "SUEK-Kuzbass" provide for a gradual increase in the volumes of production, processing, and sales (Fig. 1).

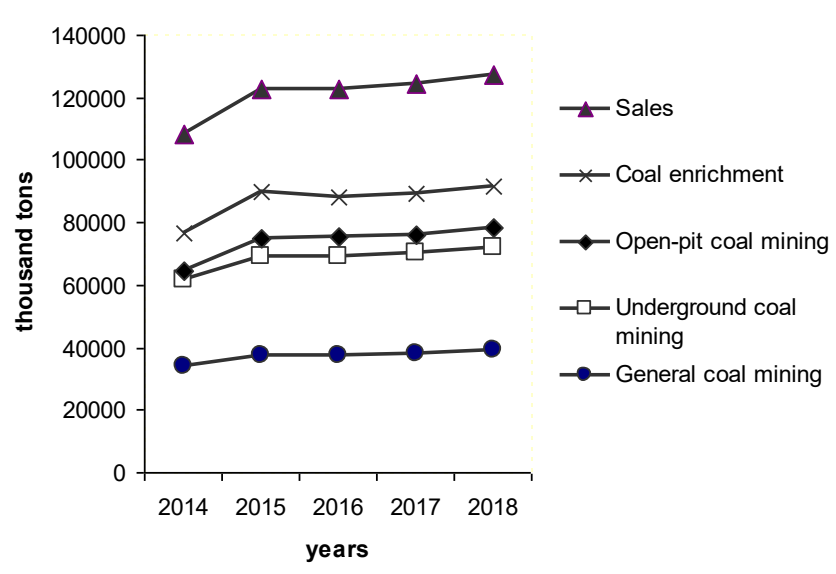

Fig. 1. Planned indicators of JSC SUEK-Kuzbass

However, despite the planned increase in production figures, the financial performance of the company over the past three years is getting worse - there is a gradual decrease in income before income taxes, interest and amortization, and net assets of the company, indicating the reduction of its investment attractiveness and market value of the property (Fig. 2). 
In addition, loss-making activity of the company before interest and taxes with an increasing trend indicates a significant amount of depreciation costs which is not offset by the earned income.

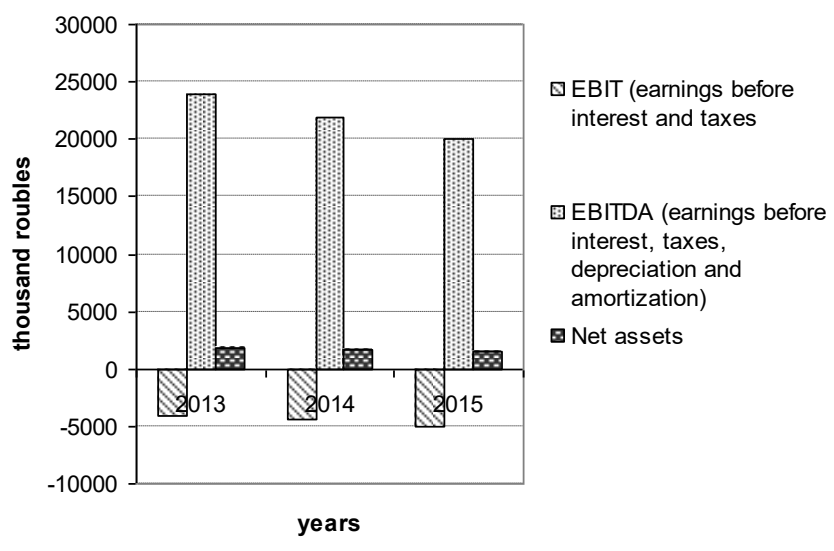

Fig. 2. Financial indicators of activity of JSC SUEK-Kuzbass

\section{MATERIALS AND METHODS}

One of the most effective actions for costs optimization and increase in efficiency of activity, including due to increase in production volumes, is creation of the system of intra corporate control using the process approach to management $[4,5]$.

Intra corporate control can be characterized as the process of corporate activity management in order to ensure efficient and profitable operations, reliable reporting and compliant to the legislation activity, i.e. efficient use of its resources, soundness of its assets, compliance with the legislative requirements $[6,7]$.

Despite existence of the legislative requirements on ensuring internal control, its organization is complicated due to indistinct formulations defining the content of the given type of control in regulations and also due to insufficient methodical recommendations on its implementation.

Effective implementation of intra corporate control assumes observance of system of the fundamental principles (fig. 3).

The body of principles is the basis of effective functioning of intra corporate control system, and the order of their combination depends on concrete circumstances [8].

Researches showed that an unambiguous technique of an assessment of intra corporate control system effectiveness in literature and normative documents isn't given, authors differ in the points of view, and in their opinion $[9,10,11,12,13$, $14,15]$, the most reliable way of defining control efficiency is the testing method on certain questions of creation of reviews of the special indicators characterizing efficiency of intra corporate control. Also, it must be kept in mind that with an effective system of intra corporate control the indicators of efficiency of the enterprise activity have to improve in dynamics. However, the dynamics of JSC SUEK-Kuzbass financial indicators for 2013-2015 (See the Table) show the deterioration of efficiency of its activity that was expressed in the growth of unprofitability of use of assets, decrease in production potential, besides, the company throughout the entire period was financially dependent on external sources and insolvent with a tendency of further deterioration.

Principles of creation of system of intra corporate control

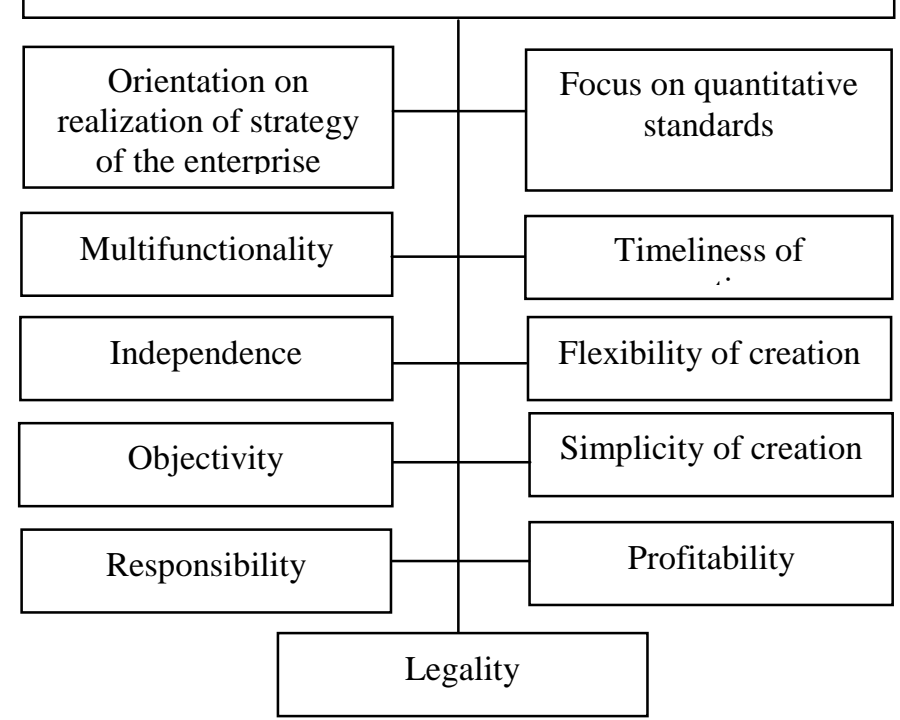

Fig. 3. Principles of creation of intra corporate control system

TABLE - Financial indicators of efficiency of JSC SUEKKuzbass activity

\begin{tabular}{|l|l|l|c|}
\hline \multicolumn{1}{|c|}{ Indicators } & $\begin{array}{l}\text { Year } \\
2013\end{array}$ & $\begin{array}{l}\text { Year } \\
2014\end{array}$ & $\begin{array}{c}\text { Year } \\
2015\end{array}$ \\
\hline $\begin{array}{l}\text { 1. Coefficient of financial } \\
\text { independence, \% }\end{array}$ & 3.15 & 1.94 & - \\
\hline $\begin{array}{l}\text { 2. Coefficient of the current } \\
\text { liquidity, \% }\end{array}$ & 23.6 & 52.74 & 33.24 \\
\hline 3. Unprofitability of assets, \% & 5.04 & 11.49 & 30.13 \\
\hline $\begin{array}{l}\text { 4. Coefficient of real cost of } \\
\text { fixed assets, \% }\end{array}$ & 78.08 & 63.53 & 65.15 \\
\hline
\end{tabular}

Results of the assessment allow judging of the need of further improvement of the internal control system existing in the company.

\section{RESULTS AND DISCUSSION}

The model of realization of the intra corporate control and assessment of its efficiency can be presented in the form of the mechanism of the organization of the intra corporate control and the mechanism of an assessment of its efficiency (Fig. 4).

The mechanism of the organization of the intra corporate control assumes stage-by-stage performance of the following actions: definition of essential risks and business processes for the coal-mining enterprises; a choice of criteria of an assessment of risks on the level of influence, probability of approach and speed of realization; drawing up the card of risks and business processes by types and criteria of an assessment; formation of a matrix of risks and business processes for an 
assessment and response; development of a matrix of control procedures for the main business processes for minimization of risks.

The mechanism of an assessment of intra corporate control assumes carrying out an assessment on separate problems of management - efficiency and profitability of operations, reliability of the reporting, compliance of activity to the current legislation, - and also an integrated assessment of intra corporate control.

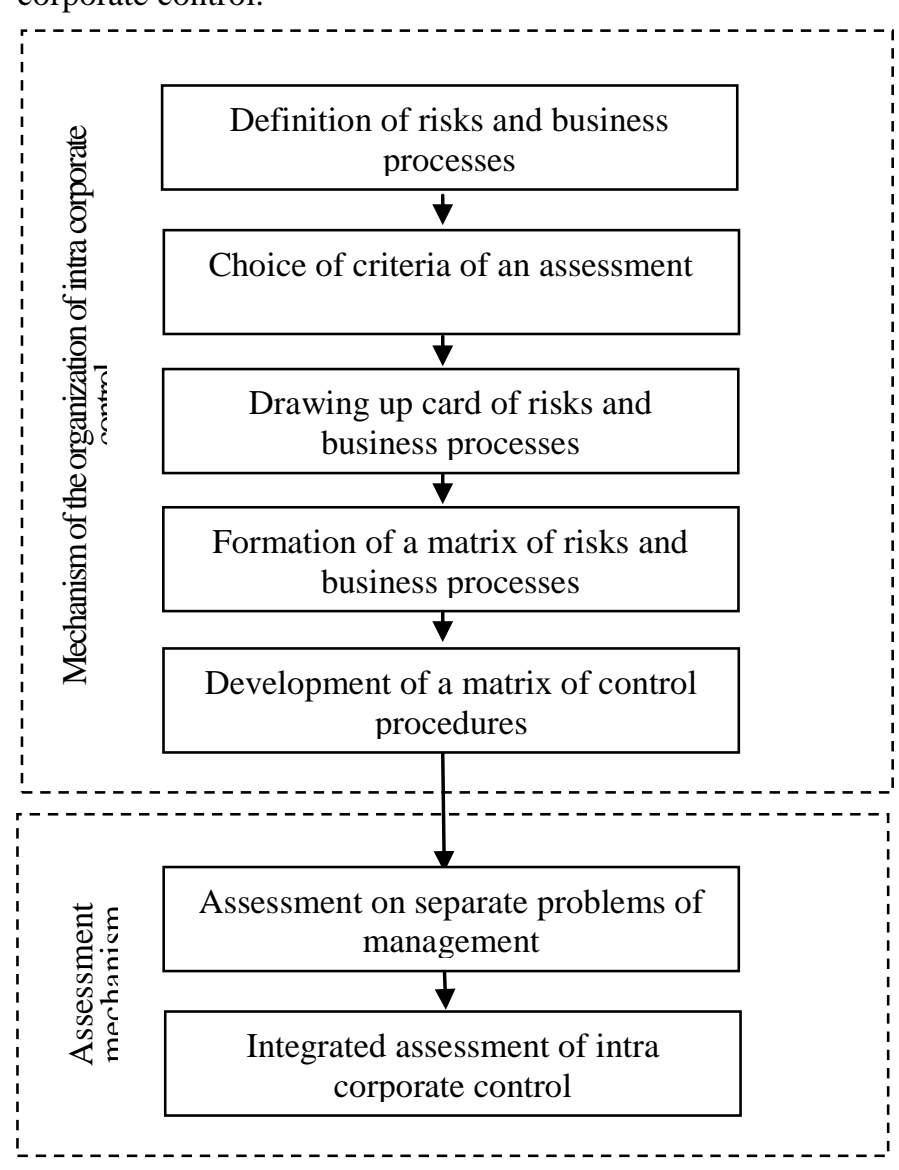

Fig. 4. Model of realization of intra corporate control

Modern approach to the organization of intra corporate control provides not only control of performance of planned indicators and ensuring reliability of corporation accounting (financial) reporting, but also detection of the risk factors capable to have impact on financial stability of corporation $[16,17]$. Classification of risks by the sphere of emergence is caused by feature of activity of the coal-mining enterprises [18]:

- commercial risks - the risks arising in the course of sales and connected with decline in demand for coal;

- technical and production risks - the risks connected with failure of the plans and obligations for production as a result of an adverse effect of environment, in particular, deterioration of mining-and-geological conditions;

- social risks - the risks caused by change of quality of manpower, professional mobility, social loyalty, in particular deterioration of preparation of the personnel at the coal mining enterprises due to the lack of system of professional training;

- environmental risks - the risks connected with probability of approach of a civil liability for causing damage to environment, and also life and human health, in particular, features of development of natural minerals [19];

- financial risks - the risks connected with possibility of failure of the financial obligations because of an economic crisis.

For determination of size of influence of risks selection of criteria of an assessment was made: level of risk influence, level of probability of risk occurrence, speed of risks realization. All risks were ranged on probability of their emergence as high, average and low. For the description and an assessment of risks of JSC SUEK-Kuzbass the card of risks which represents the list of all risks of the company is made, allows to range risks on their importance, effectively to trace changes. The card of risks determining the level of risk influence, probability of its approach and speed of realization is created on the basis of data of accounting (financial) reporting. The generalizing assessment of risks is carried out on the basis of a matrix of risks on business processes proceeding from criteria of the risks accepted for an assessment and business processes specific for the coal mining enterprises. After an evaluation stage of risks follows the stage of response to risk on which development of actions for risk management, that is control procedures (set of the methods and rules used by management for receiving confidence that the objectives of control will be achieved) is necessary.

The matrix of control procedures is developed on the basis of the analysis of the card of risks of a number of the coal mining companies and represents the list of all developed control procedures on business processes in using of process approach risks probability, level of influence and speed of realization is established. Depending on specifics of coal mining industry the business processes having direct influence on the reporting were allocated: purchase and stockpile management, coal mining, sales, finance, forecasting and budgeting, account and reporting, taxes, information technologies, personnel, safety of production. In each of these business processes existence of control procedures which ultimate goal is providing to authors of the reporting full and the correct entering information for preparation of the reporting and the list of control procedures for minimization of the corresponding risk is supposed. Using of control procedures will allow to operate risks of company on business processes, and also to reduce period of procedures of external audit, therefore, to cut expenses on annual audit.

For the solution of this task web product ARIS Audit Manager allowing to automate procedures of testing, creations of the reporting under its results, working on the basis of ARIS is used. This product is the decision on management of business processes leading in the market, providing the enterprise with all documentation necessary for coverage of all life cycle of system of intra corporate control (from documenting and testing before monitoring) [20]. 
The following methods serve as the most important instrument of control of profitability of operations:

1) The analytical coefficients characterizing ratios between various indicators of accounting (financial) reporting. Calculating of financial indictors and their comparison to their industry average values are the first step of intra corporate control [21].

2) For an assessment and control of activity and the administrative personnel efficiency the KPI technique is used (Key Performance Indicators, or Key indicators of efficiency). It is a system of an assessment for definition of achievement of operational and strategic objectives of the enterprise [13]. KPI helps the company to estimate the current situation and to increase efficiency of realization of own strategy of development.

\section{3) Indicators of estimation of cost of business.}

\section{4) Integrated assessment.}

For an assessment of efficiency of achievement of such purposes as reliability of the reporting and compliance of activity to the legislation matrixes of control procedures for business processes are used. For an integrated assessment of intra corporate control the matrix of an assessment of results of the integrated analysis on the basis of a mark method can be used.

\section{CONCLUSIONS}

In relation to the coal mining enterprises, in particular, of JSC SUEK-Kuzbass, the new method of a solution of the problem of creation of intra corporate control system which includes the mechanism of formation of matrixes of control procedures with use of matrixes of risks for business processes taking into account the branch specifics, and a technique of an assessment of intra corporate control system effectiveness is offered, and also documentary providing of this system is developed. Need of the organization and an assessment of intra corporate control efficiency with use of a complex of tools is caused by realization of a main objective of intra corporate control increase of efficiency of enterprise activity that will allow to make quickly management decisions on increase in business processes productivity.

\section{REFERENCES}

[1] Lakhno Yu. V. Russian Coal Industry: Threats and possibilities. Studies on Russian Economic Development. 2015. Vol. 26, No. 5. P. 476-482.

[2] Porfiriev B. N. New Global Trends in Energy Power Development challenges and risks for the Russia integration into the word economy. Studies on Russian economic development. 2015. Vol. 26, No. 1. P. 3236.

[3] Data on performance of the federal budget [Dannye ob ispolnenii federalnogo byudzheta]. URL: http://www .minfin.ru/ru/statistics/fedbud/index.php\#. (Accessed: 10.02.2016).

[4] Korshunova E. D., Popov O. V. Adaptatsiya operatsionnoy deyatelnosti promyshlennogo predpriyatiya $\mathrm{v}$ usloviyarh vykhoda iz krizisa: primenenie instrumentov protsessnogo upravleniya [Adaptation of operating activities of the industrial enterprise in the conditions of recovery from the crisis: use of instruments of process management]. Vestnik MGTU "Stankin" [Bulletin of MGTU of "Stankin"]. 2011. No.

\section{P. $105-108$}

[5] Ivanova T. N. Teoreticheskie osnovy sozdaniya i funktsionirovaniya system vnutrennego kontrolya [Theoretical bases of creation and functioning of systems of internal control]. Vestnik professionalnykh bukhgalterov [Messenger of professional accountants]. 2011. No. 1. P. 19-23.

[6] Kucherova E. V., Ostanina E. V., Tyuleneva T. A., Cherepanova N. A. Vnutrenniy finansovyy control kak obyazatelnoe uslovie effektivnosti deyatelnosti korporatsii [Internal financial control as indispensable condition of efficiency of activity of corporation]. Vestnik Kuzbasskogo gosudarstvennogo tekhnicheskogo universiteta [Bulletin of the Kuzbass state technical university]. 2015. No. 1. P. 126-129.

[7] Cherepanova N. A. Vnutrikorporativnyy finansovyy control kak odin iz faktorov ustoychivogo razvitiya ugolnykh predpriyatiy (na primere OAO "SUEK-Kuzbass") [Intra corporate financial control as one of factors of a sustainable development of the coal enterprises (on the example of JSC SUEK Kuzbass)]. Vestnik Kuzbasskogo gosudarstvennogo tekhnicheskogo universiteta [Bulletin of the Kuzbass state technical university]. 2015. No. 4. P. 152-158.

[8] Serebryakova T. YU. Riski organizatsii i vnutreniy ekonomicheskiy control [Risks of the organization and internal economic control]. Moskva, INFRA-M, 2013. $111 \mathrm{P}$.

[9] Chambers A., Rand G.. The Operational Auditing Handbook: Auditing Business and IT Processes. Wiley \& Sons. 2010. P. 28.

[10] Harley E. Ryan, Jr. Corporate Financial Control Mechanisms and Firm Performance: The Case of Value-Based Management Systems. Journal of Business Finance and Accounting. 2006. No. 9. P. 7. (2)

[11] Robert P. Greenwood Handbook of Financial Planning and Control. TJ International, Ltd, 2002. P. 7. (4)

[12] Knorring V. I. Teoriya, praktika i iskusstvo upravleniya [Theory, practice and management skill]. Moskva, Izdatelstvo NORMA [Moskov, Publishing house NORM]. 2001. 528 P.

[13] Alekseev B. A. Sbalansirovannaya sistema pokazateley: adaptatsiya i sposoby primeneniya [Balanced system of indicators: adaptation and methods of application]. Aktualnye problemy sotsialnoekonomicheskogo razvitiya Rossii [Actual problems of social and economic development of Russia]. 2010. Vo. 4 P. 105-108.

[14] Fayol Anri. Obshchee i promyshlennoe upravlenie [General and industrial department]. Moskva, Zhurnal "Kontrolling" [Moskow, Kontrolling magazine]. 1992. $111 \mathrm{P}$

[15] Horngren CH. T., Foster D. ZH. Bukhgalterskiy uchet: upravlencheskiy aspect [Accounting: administrative aspect]. Moskva, Finansy i statistika [Moskow, Finance and statistics]. 1997. P. 9. (10)

[16] Fridman YU. A., Rechko G. N., Alerseenko E. V., Lyamin A. YU. Ugolniy biznes: factory riska [Coal business: risk factors]. Vestnik Kuzbasskogo gosudarstvennogo tekhnicheskogo universiteta [Bulletin of the Kuzbass state technical university]. 2012. No. 2. P. 117-124.

[17] Kaurova O. V., Kryukova YU. G.. Vnutrenniy finansoviy control Internal financial control. Finansoviy vestnik: nalogi, strakhovanie, bukhgalterskiy uchet [Financial messenger: finance, taxes, insurance, accounting]. 2009. No. 1. P. 135-160.

[18] Khakhonova I. I. Razvitie metodiki upraleniya finansovymi riskami [Internal financial control]. Fundamentalnye issledovaniya [Basic researches]. 2012. No. 6-1. P. 268-272.

[19] Mirhaylov V. G., Koryakov A. G., Mikhaylov G. S. Upravlenie ekologicheskimi riskami $\mathrm{v}$ protsesse dobychi i pererabotki uglya [Development of a technique of management of financial risks]. Fizikotekhnicheskie problemy razrabotki poleznykh iskopaemykh [Physics and technology problems of development of minerals]. 2015. No. 5. P. 8391.

[20] Koptelov A. Podkhody k postroeniyu system vnutrennego kontrolya [Approaches to creation of systems of internal control]. Finansovaya gazeta [Financial newspaper]. 2007. No. 39. P. 2.

Sheremet A. D., Negashev E. V. Metodika finansovogo analiza deyatelnosti kommercheskikh organizastiy [Metodika of the financial analysis of activity of the commercial organizations]. Moskva, INFRA-M

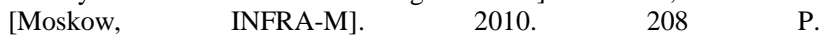


